\title{
PENINGKATAN KREATIFITAS DAN INISIATIF GURU MELALUI MODEL PEMBELAJARAN DARING PADA MASA PANDEMI COVID-19
}

\author{
Suciati \\ SD Bungkus \\ jafarsuci2@gmail.com
}

\begin{abstract}
Abstrak: Penelitian ini bertujuan untuk mengetahui model pembelajaran daring dalam meningkatkan kreatifitas dan inisiatif guru dalam mengelola pembelajaran di rumah di SD Bungkus. Jenis penelitian yang dilakukan yaitu penelitian tindakan sekolah (PTS) dengan menggunakan model dari Elliot. Penelitian diadakan di SD Bungkus Kretek, Bantul pada tahun pelajaran 2019/2020 di masa pandemi Covid 19. Subjek penelitian adalah guru kelas 1, 2, 3, 4, dan guru kelas 5. Obyek penelitian adalah pembelajaran di rumah melalui pembelajaran daring/online dimasa pademi covid-19. Data dikumpulkan melalui observasi dan dokumentasi serta dianalisi secara kualitatif. Hasil penelitian ini menunjukkan bahwa model pembelajaran daring dapat mengatasi pelaksanaan pembelajaran di masa pademi covid 19 melalui kreatifitas dan inisiatif guru dalam mengelola pembelajaran di rumah. Kreatifitas dan inisiatif guru mengalami peningkatan dalam pembuatan RPP sebesar $18 \%$, pengelolaan pembelajaran daring sebesar $12 \%$, keaktifan siswa sebesar 17\% dan nilai belajar siswa sebesar 9,6\% dari siklus I ke siklus II dalam pembelajaran. Setelah ada tindakan kompetensi guru secara aktif, kreatif dan inisiatif dalam melaksanakan pembelajaran dirumah, pembelajaran dapat berjalan dengan lancar dalam mengahadapi wabah pandemi covid 19.
\end{abstract}

Kata kunci: pembelajaran daring, keaktifan, kreatifitas, inisiatif

\section{IMPROVEMENT OF TEACHER CREATIVITIES AND INITIATIVES THROUGH ONLINE LEARNING MODELS IN THE COVID-19 PANDEMIC PERIOD}

\begin{abstract}
This study aims to determine the online learning model in increasing the creativity and initiative of teachers in managing learning at home in SD Bungkus. This type of research is a school action research (PTS) using a model from Elliot. The study was conducted at SD Bungkus Kretek, Bantul in the 2019/2020 academic year during the Covid pandemic 19. The research subjects were grade 1, 2, 3, 4, and grade 5 teachers. The object of the study was home learning through online I online learning in the future pademi cavid 19. Data collected through observation and documentation and analyzed qualitatively. The results of this study indicate that online learning models can overcome the implementation of learning in the Pademus 19 period through the creativity and initiative of teachers in managing learning at home. Teacher creativity and initiative have increased in the making of lesson plans by $18 \%$, online learning management by $12 \%$, student activity by $17 \%$ and student learning values by $9.6 \%$ from cycle I to cycle II in learning. After active teacher action, creative competence and initiative in implementing learning at home, learning can proceed smoothly in the face of the covid-19 pandemic outbreak.
\end{abstract}

Keywords: online learning, activeness, creativity, initiative

\section{PENDAHULUAN}

Pada tanggal 11 Maret 2020 WHO telah mengumumkan status pandemi global untuk virus corona 2019 atau juga disebut Corona Virus Disease 2019 atau Covid 19 Wabah atau penyakit ini telah menyerang banyak korban, serempak di berbagai negara. WHO menetapkan seluruh warga dunia bisa berpotensi terkena infeksi Covid 19, guru dan siswa juga bisa terinfeksi Covid 19 (kompas.com).

Pemerintah mengambil kebijakan agar anak belajar di rumah. Hal ini diatur dalam UU No. 6 Tahun 2018 tentang Kekarantinaan
Kesehatan yang kemudian dipertegas dengan PP No. 21 Tahun 2020 dan Permenkes 9 tahun 2020 tentang Pembatasan Sosial Berskala Besar (PSBB).

Pemerintah memberikan kebijakan agar anak belajar di rumah. Pembelajaran siswa dirumah membuat para orang tua senang dan tenang, dikarenakan anak bisa selalu bersama orang tuanya, dengan maksud meminimalisir penyebaran covid-19. Anak kurang memaksimalkan dalam penggunaan teknologi tidak begitu efektif dan efisen. Guru memberikan tugas secara online. Komunikasi juga jadi hanya satu arah. Sehingga tidak efektif 
dan efisien di dalam pembelajaran maka kita harus mengambil langkah langkah yang pasti agar anak dirumah bisa belajar dengan baik.

Dalam kaitannya dengan proses pembelajaran guru dimasa wabah covid 19 hendaknya dapat mengarahkan dan membimbing siswa secara aktif dalam kegiatan pembelajaran di rumah sehingga tercipta interaksi yang baik antara guru dengan peserta didik melalui online. bahwa terjadinya proses pembelajaran ditandai dengan dua hal yaitu (1) siswa menunjukan keaktifan, seperti tampak dalam jumlah curahan waktu untuk melaksanakan tugas, (2) terjadi perubahan perilaku yang selaras dengan tujuan pengajaran yang diharapkan

Di dalam Undang-Undang RI Nomer 20 tahun 2003, tentang Sistem Pendidikan Nasional Bab XI Pasal 39 ayat (1), dijelaskan tenaga kependidikan bertugas melaksanakan administrasi, pengelolaan, pengembangan dan pelayanan teknis untuk menunjang proses pendidikan dan satuan pendidikan

Menurut pernyataan diatas guru bertugas melaksanakan pengelolaan, pengembangan dan pelayanan teknis untuk menunjang proses pendidikan dalam satuan pendidikan, dari hasil Penulis di Sekolah Dasar masih ada guru yang belum mampu menerapkan pembelajaran dirumah melalui online dikarenakan keterbatasan dalam teknologi, Kondisi tersebut terjadi hampir disebagian besar guru di Sekolah Dasar masih banyak guru yang menerapkan model pembelajaran dengan tugas banyak tanpa memperhatikan situasi dan kondisi dimasa wabah covid-19 ini, harusnya anak dibuat senang agar imun atau daya tahan tubuh pada anak bisa terjaga dengan baik, jangan pembelajaran hanya monoton dan dengan menggunakan model pembelajaran yang kreatif menyenangkan dan tidak membosankan anak, karakter dan kreatif anak harus terus kita bina. Pemberian materi yang terlalu banyak dan melelahkan anak membuat anak kehilangan selera belajar.

\section{METODE PENELITIAN}

Tempat penelitian tindakan sekolah ini di SD Bungkus yang beralamatkan Bungkus, Parangtritis, Kretek, Bantul Daerah Istimewa Yogyakarta. SD Bungkus memiliki jumlah peserta didik 100. Jumlah guru kelas 6, guru bidang studi 4, seorang kepala sekolah dan seorang operator. Secara geografis SD Bungkus terletak di desa, jauh dari perkotaan.
Sisi Barat sekolah dekat dengan Sungai Opak, sedangkan sisi selatan sekolah merupakan pantai.

Penelitian dilaksanakan pada semester II tahun pelajaran 2019/2020 pada bulan Maret sampai dengan Mei 2020. Subjek penelitian adalah guru di SD Bungkus. Guru kelas di SD Bungkus sejumlah 6 digunakan sebagai subjek penelitian dengan pertimbangan: pelaksanaan pembelajaraan BDR dimasa pandemi covid 19 melalui daring. Sesuai dengan UU RI Nomor 20 Tahun 2003 tentang Sistem Pendidikan Nasional. Dalam Pasal 31 Ayat 2 UU RI di atas juga disebutkan pendidikan jarak jauh berfungsi memberikan layanan pendidikan kepada kelompok masyarakat yang tidak dapat mengikuti pendidikan secara tatap muka atau reguler. Dengan adanya peningkatan kreatifitas dan inisiatif guru dalam menyampaikan materi, pembelajaran diharapkan akan membuat siswa senang, tertarik, menantang dan tidak bosan belajar di rumah didampingi orang tua, adapun penilaian yang dilakukan oleh guru dimasa pandemi covid-19, sesuai dengan nilai pada pelaksanaan ulangan harian sebelumnya covid-19 yang dilaksanakan dikelas rendah yaitu 69 di bawah nilai KKM 75. Berdasarkan pengamatan dan supervisi peneliti dalam pembelajaran dikelas dan pembelajran masa pademi covid-19 yaitu pembelajaran dirumah atau sering disebut BDR (Belajar di Rumah) mengenai guru, siswa, orang tua dan hasilnya. Target yang ingin dicapai pembelajaran BDR yaitu semua materi tersampaikan dengan tidak mengurangi hak anak dalam masa pademi covid-19 yaitu guru harus melaksanakan pembelajaran secara aktrif kreatif, penuh inisiatif, berkarakter, menyenagkan, dan menantang dengan hasil sesuai harapan tanpa mengurangi imun anak dan bisa menambah imun anak dimasa pademi covid-19 ini agar kekebalan anak tidak menurun hasil pengamatan yang dilakukan oleh peneliti yaitu antara guru siswa dan orang tua harus benar-benar kompak dan tahu akan tugas dan kewajiban masing masing dimasa pandemi covid-19 ini untuk mencapai hasil yang diharapkan, dalam pembelajaran daring di rumah atau BDR melalui daring nilai hasil supervisi yang dilakukan kepala sekolah sesuai dengan kompetensi supervisi kepala sekolah yaitu Permendikbud no 13 tahun 2007 tentang standar kompetensi kepala sekolah dari segi guru semakin canggih dalam penggunakan alat teknologi, lebih berfikir kreatif untuk 
menyampaikan tugas tugas yang diberikan kepada siswa agar menyenangkan, tidak membosankan dan menarik, guru harus lebih inisiatif agar materi tersampaikan dengan baik dan benar. Sedangkan target yang harus dicapai Tersampaikan semua materi pembelajaran di semester II Pandemi covid-19, keadaan seperti itu menunjukkan adanya kesenjangan antar harapan dan kondisi nyata di sekolah. Berdasarkan pertimbangan tersebut, maka guru kelas 1, 2, 3, 4 dan 5 ditetapkan peneliti sebagai subjek penelitian.

Penelitian tindakan sekolah ini menggunakan model siklus dari Elliot, setiap siklus terdiri atas empat tahap kegiatan yaitu: the planning of the action (rencana tindakan), the implementation of the action (implementasi tindakan), classroom observation (observasi kelas), dan the reflection of the action (refleksi tindakan). Tindakan yang diterapkan pada subjek dalam penelitian ini adalah meningkatkan kemampuan mengelola pembelajaran BDR melalui model daring.

Penelitian ini dilaksanakan dalam 2 siklus dimana setiap siklus terdiri dari 4 tahapan yaitu: (1) the planning of the action (perencanaan), (2) the implementation of the action (implementasi tindakan), (3) class observation or monitoring and evaluation (observasi kelas dan evaluasi), (4) data analysis and reflection of the action (analisis data dan refleksi tindakan).

Kegiatan yang dilakukan dalam planning adalah merencanakan pembinaan terhadap guru pada pembelajaran BDR. Pembinaan dilakukan dengan diskusi, dengan mentaati anjuran pemerintah pakai masker, jaga jarak dan gunakan handsanitizer atau cuci tangan pakai sabun pada air yang mengalir. Penjelasan tentang pengelolaan pembelajran BDR dan merencanakan pemodelan. Peneliti membuat RPP pembinaan terhadap guru, RPP pemodelan, membuat instrumen observasi dan menyusun jadwal. Pada tahap perencanaan ini penulis melaksanakan persiapan sebagai berikut: merencanakan pembinaan terhadap guru; membuat Rencana Pelaksanaan Pembelajaran model daring; menyusun mediadan rencana pembelajaran BDR yang disampaikan melalui online atau daring; membuat intrumen penelitian; lembar observasi RPP pembimbingan; lembar observasi pembimbingan; lembar observasi RPP melalui daring; lembar observasi keterlibatan siswa dalam KBM model daring; lembar observasi pengelolaan pembelajaran BDR model darin; lembar observasi RPP guru dalam pembelajaran daring; lembar observasi keterlibatan siswa dalam pembelajaran BDR; lembar observasi pengelolaan pembelajaran melalui daring / guru memberikan tugas melalui daring atau online, membuat jadwal penelitian; melakukan validasi instrumen penelitian dengan melibatkan kolaborator melalui online.

Acting mencakup pelaksanaan bimbingan dan pemodelan. Melaksanakan bimbingan terhadap guru melalui daring /online yang menjadi subjek penelitian. Tahap ini peneliti melakukan diskusi dengan guru tentang pengelolaan pembelajaran BDR melalui Daring/Online yang baik. Beberapa hal yang disampaikan tentang pengertian pengelolaan pembelajaran BDR melalui daring, prinsipprinsip pengelolaan pembelajaran BDR melalui daring, tujuan pembelajaran BDR melalui model daring, keterampilan pengelolaan pembelajaran BDR melalui daring, serta kendala-kendala yang dihadapi guru dalam pengelolaan Pembelajara daring. Setelah diskusi melalui daring selesai, dilanjutkan dengan pemodelan pembelajaran daring. Tindakan atau perlakuan yang diterapkan dalam penelitian ini adalah subjek penelitian mengobservasi guru dalam pembelajaran BDR melalui daring atau online dengan mengunakan instrumen observasi pengelolaan pembelajaran BDR melalui daring atau online dengan cara mengikuti pembelajaran BDR melalui daring atau online dalam grup pembelajaran daring perkelas. Setelah selesai mengobservasi dilakukan diskusi melalui pertemuaan guru dalam piket bersama digunakan untuk mengevaluasi dan berdiskusi tentang pembelajaran BDR melalui daring antara peneliti dengan subjek penelitian.

Observing berupa mengamati guru dalam menyusun perencanaan pembelajaran BDR melalui daring/online dan pelaksanaan proses pembelajaran BDR. Pada tahap observing, peneliti mengobservasi subjek penelitian dalam membuat RPP, mengobservasi kegiatan belajar mengajar melalui daring dan mengobservasi keaktifan siswa dalam kegiatan pembelajaran BDR. Fokus observasi pada pengelolaan pemberian tugas melalui daring dan respon siswa dalam mengikuti pembelajaran BDR. Observasi pembuatan RPP dimaksudkan untuk mengamati tugas tugas yang diberikan oleh siswa melalui daring/online dan metode serta skenario pembelajaran BDR yang digunakan guru. Observasi menggunakan lembar instrumen observasi. Observasi dilakukan oleh 
kepala sekolah melalui daring. Di akhir pembelajaran BDR guru melakukan penilaian. Penilaian ini juga dicatat sebagai nilai hasil belajar siswa dalam mengerjakan tugas tugas dirumah melalui daring/online yang juga menjadi indikator kompetensi guru dalam pembelajaran daring.

Reflecting berupa membandingkan kompetensi gurudalam pembelajara daring dengan indikator keberhasilan. Kompetensi guru dan indikator keberhasilan dibuat dalam data kuantitatif. Kompetensi guru berupa kemampuan mengelola pembelajara BDR dilihat dari hasil observasi pembuatan RPP, pelaksanaan pembelajaran BDR melalui daring, dan keaktifan siswa dalam dalam mengerjakan tugas tugas dalam pembalajara BDR melalui daring/online. Indikator keberhasilan sudah ditentukan $75 \%$. Lembar observasi RPP berisi beberapa hal yang harus ada dan yang harus dilakukan guru dalam membuat RPP.

Instrumen yang digunakan berbentuk ratingscale yaitu alat untuk memperoleh data yang berupa suatu daftar yang berisi tentang sifat/ciri-ciri tingkah laku subjek penelitian yang ingin diselidiki yang harus dicatat secara bertingkat. Jenis rating yang digunakan adalah skala numeris. Angka dalam kebanyakan skala rating digunakan sebagai anchor, dan penggunaan angka ini didefinisikan secara jelas. Di belakang setiap deskripsi disediakan ruang untuk membubuhkan tanda $\sqrt{ }$ yang menunjukkan kesesuaiannya dengan subjek yang diamati. Observer hanya menandai angka yang menjadi pilihannya yaitu angka $1-4$. Masing-masing angka memiliki makna tersendiri. $1=$ kurang, $2=$ cukup, $3=$ baik, $4=$ sangat baik. Hasil dari rating seluruh item yang menjadi pilihan observer dijumlahkan kemudian dibandingkan dengan indikator keberhasilan. Misalnya seluruh rating dari semua item 4 sehingga jumlah rating 100. Maka kompetensi guru tersebut $100 \%$. Nilai seratus dibandingkan dengan indikator keberhasilan yaitu $85 \%$. Perbandingan antara kompetensi guru dan indikator keberhasilan adalah 100\%: $85 \%$. Ini berarti Guru sudah memiliki kompetensi yang tinggi. Jika hasil rating $65 \%$ maka perbandingan antara kompetensi guru dan indikator keberhasilan adalah 65\%: 85\%. Ini berarti Guru memiliki kompetensi yang rendah. Jika perbandingan antara kompetensi guru lebih rendah dibanding dengan indikator keberhasilan maka dilanjutkan ke siklus kedua.
Penelitian ini menggunakan dua macam data yaitu primary data (data utama) dan supporting data (data pendukung). Data utama berupa hasil observasi kreatifitas dalam pembuatan RPP, hasil observasi inisiatif dalam pengelolaan kelas saat subjek penelitian mememberikan tugas melalui daring/online, dan hasil observasi keaktifan siswa dalam mengerjakan tugas tugas dalam pembelajara BDR melalui daring/online. Data pendukung berupa hasil pengerjaan tugas akhir pelajaran. Instrumen yang digunakan berbentuk ratingscale yaitu alat untuk memperoleh data yang berupa suatu daftar yang berisi tentang sifat/ciri-ciri tingkah laku subjek penelitian yang ingin diselidiki yang harus dicatat secara bertingkat. Jenis rating yang digunakan adalah skala numeris. Observer atau rater hanya menandai angka yang menjadi pilihannya yaitu angka 1 - 4. Masing-masing angka memiliki makna tersendiri. $1=$ kurang, $2=$ cukup, $3=$ baik, $4=$ amat baik. Hasil dari rating seluruh item yang menjadi pilihan observer dijumlahkan kemudian dibandingkan dengan indikator keberhasilan.

Teknik analisis data dalam penelitian ini melalui beberapa tahap. Data yang diperoleh berupa lembar observasi dalam proses pembelajaran BDR melalui daring/online, yaitu lembar observasi pengelolaan pembelajara daring/online dan lembar observasi keaktifan siswa dalam mengerjakan tugas pembelajaran BDR melalui daring, serta tes hasil belajar siswa pada akhir siklus (atau setiap pertemuan). Data yang dianalis adalah: Analisis data obsrvasi pengelolaan pengerjaan tugas BDR dan observasi keaktifan siswa mengerjakan tugas pembelajaran BDR melalui daring/online, serta tes hasil belajar siswa pada akhir siklus. Analisis menggunakan rerata hasil observasi dan tes, selanjutnya hasil rerata dideskripsikan untuk masing masing instrumen. Analisis deskriptif ini digunakan untuk mendeskripsikan karakteristik data hasil penelitian dan menjawab permasalahan pada rumusan masalah. Analisis deskriptif yang digunakan untuk data prestasi siswa adalah skor minimum, skor maksimum, rerata, dan presentase. Berdasarkan kriteria ketuntasan belajar apabila mencapai nilai minimal 75 untuk skala 100. Sedangkan untuk observasi RPP, pengelolaan pembelajaran BDR melalui daring/online, dan keterlibatan siswa dalam mengerjakan tugas daring/online nilai pencapaiannya dikatakan berhasil jika rata-rata persentase siswa mencapai minimal 75 . 


\section{HASIL DAN PEMBAHASAN}

Prasiklus kondisi pembelajaran masa pandemi covid-19 melalui daring/online pada pra siklus masih konvensional. Kemampuan guru dalam melaksanakan pembalajaran BDR masih rendah, hal ini dapat dilihat dari suasana pembelajaran BDR melalui daring yang kurang kondusif, aktifitas siswa yang kurang terkontrol, minat siswa dalam belajar kurang, siswa tidak semangat dalam melaksanakan kegiatan pembelajaran BDR, kurang motivasi, sehingga berdampak pada rendahnya nilai belajar siswa. Data hasil supervisi akademik pada prasiklus terangkum pada tabel berikut.

Tabel 1: Rangkuman hasil supervisi akademik dalam masa pademi covid-19 Pra Siklus

\begin{tabular}{lcc}
\hline \multicolumn{1}{c}{ Item } & Nilai Rata-rata supervisi & Indikator keberhasilan \\
\hline Kreatifitas dalam Penyusunan RPP & $72 \%$ & $85 \%$ \\
Inisiatif Pengelolaan Pembelajaran Daring & $72 \%$ & $85 \%$ \\
Keaktifan Siswa & $69 \%$ & $85 \%$ \\
Nilai Siswa & $69 \%$ & $75 \%$ \\
\hline
\end{tabular}

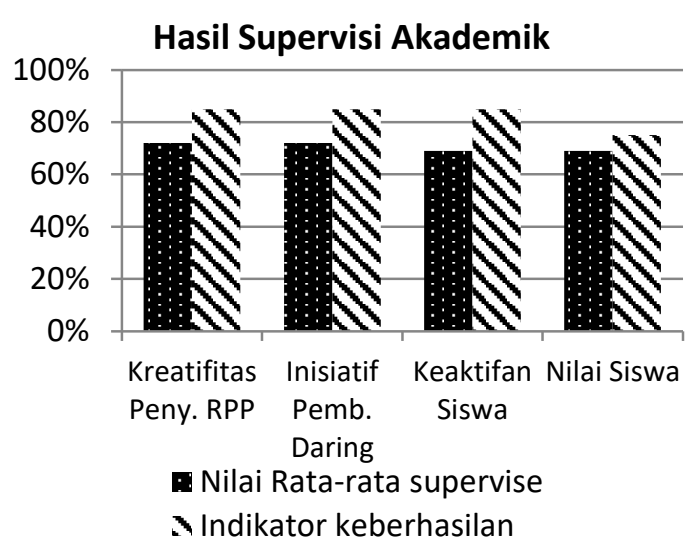

Gambar 1. Rangkuman hasil supervisi akademik dalam masa pademi covid-19 Pra Siklus

Pada Tabel 1 memberikan gambaran bahwa kompetensi guru dalam membuat RPP, pemberian tugas daring, keaktifan siswa masih jauh di bawah indikator keberhasilan. Kenyataan tersebut terjadi karena kompetensi guru di bidang pembelajaran BDR masih rendah. Proses pembelajaran cenderung menyampaikan materi kepada siswa. Pengelolaan kelas tidak optimal, perhatian terhadap siswa kurang menyeluruh.

Penelitian Tindakan Sekolah pada siklus I dilaksanakan pada bulan Maret 2020. Kegiatan Siklus I meliputi perencanaan, implementasi tindakan, observasi, dan analisis data serta refleksi tindakan. Kegiatan yang dilakukan dalam perencanaan adalah merencanakan pembinaan terhadap guru. Pembinaan dilakukan dengan diskusi, penjelasan tentang pembelajaran BDR melalui daring/online dan merencanakan pemodelan. Peneliti membuat RPP pembinaan terhadap guru, RPP pemodelan, membuat instrument observasi dan menyusun jadwal. Acting mencakup pelaksanaan bimbingan dan pemodelan. Observing berupa mengamati guru dalam pembelajaran daring/online dengan ikut dalam group masing masing kelas pembelajaran dalam menyusun perencanaan dan pelaksanaan proses belajar mengajar melalui daring. Sedangkan reflecting berupa membandingkan kompetensi guru dengan indikator.

Pada tahap pelaksanaan kegiatan ini peneliti melakukan pembinaan tentang pembelajaran BDR melalui daring/online dengan sistem diskusi, penyampaian materi, dan pemberian contoh pembelajaran BDR melalui daring/online. Setelah pembinaan selesai dilakukan, langkah selanjutnya adalah observasi. Observasi dalam daring dilakukan dengan ikut dalam group perkelas dalam pembelajaran daring melalui online dilakukan dengan tujuan untuk mengetahui tingkat partisipasi atau keaktifan siswa dalam proses pembelajaran. Hal ini juga sebagai bentuk evaluasi terhadap proses pembelajaran. Lembar observasi yang digunakan berupa lembar checklist. Indikator yang diamati adalah tingkat partisipasi siswa dalam pengerjaan tugas tugas yang diberikan oleh guru melalui daring/online.

Tabel 2: Rangkuman Analisis Hasil Observasi Siklus I

\begin{tabular}{lcccccccc}
\hline \multirow{2}{*}{ Item } & \multicolumn{5}{c}{ Nilai Observasi Guru } & \multirow{2}{*}{ Rerata } & $\begin{array}{c}\text { Indikator } \\
\text { keberha-silan }\end{array}$ & Kesenjangan \\
\cline { 2 - 6 } & I & II & III & IV & V & & $16 \%$ \\
\hline $\begin{array}{l}\text { Kreatifitas dalam } \\
\text { Penyusunan RPP }\end{array}$ & $67 \%$ & $73 \%$ & $66 \%$ & $74 \%$ & $65 \%$ & $69 \%$ & $85 \%$ & $9 \%$ \\
\hline $\begin{array}{l}\text { Inisiatif Pengelolaan } \\
\text { Pembelajaran Daring }\end{array}$ & $77 \%$ & $77 \%$ & $74 \%$ & $80 \%$ & $72 \%$ & $76 \%$ & $85 \%$ & $13 \%$ \\
\hline Keaktifan Siswa & $74 \%$ & $73 \%$ & $73 \%$ & $74 \%$ & $66 \%$ & $71 \%$ & $85 \%$ & $4,6 \%$ \\
\hline Nilai Siswa & $72 \%$ & $70 \%$ & $70 \%$ & $71 \%$ & $69 \%$ & $70,4 \%$ & $75 \%$ & 9 \\
\hline
\end{tabular}


Tabel 2 dapat dibaca bahwa hasil observasi RPP terhadap guru kelas 1, guru kelas 2, guru kelas 3, guru kelas 4, dan guru kelas 5 dari kelima guru yang menjadi subjek penelitian mendapat skor $69 \%$. Hasil observasi terhadap pengelolaan kelas mendapat skor $76 \%$. Hasil observasi terhadap keaktifan siswa mendapat skor $72 \%$. Hasil observasi terhadap nilai yang diperoleh siswa mendapat skor $70,4 \%$. Dari kelima item yang diobservasi skor terendah pada kemampuan membuat RPP. Sedangkan perolehan skor tertinggi pada kompetensi pengelolaan kelas yaitu mendapat skor $76 \%$.

Berdasarkan skor capaian kompetensi guru masih lebih rendah dibandingkan dengan indikator keberhasilan. Kompetensi pembuatan RPP mendapatkan skor 69\%, sementara indikator keberhasilan $85 \%$. Ini berarti masih ada kesenjangan $7 \%$. Hasil observasi terhadap pengelolaan kelas mendapat skor $76 \%$ dan hasil observasi terhadap keaktifan siswa mendapat skor $71 \%$ sedangkan indikator keberhasilan $85 \%$. Ini berarti masih ada kesenjangan $12 \%$. Hasil observasi terhadap nilai yang diperoleh siswa mendapat skor $70,4 \%$, sementara indikator keberhasilan $75 \%$. Ini berarti masih ada kesenjangan $4,6 \%$. Oleh karena itu untuk mencapai ketuntasan dilanjutkan dengan siklus II.

Siklus II dilaksanakan pada tanggal 23 Maret sampai dengan 11 April 2020. Pada tahap perencanaan peneliti melaksanakan kegiatan: a) menyusun perencanaan pembinaan terhadap guru, b) menyusun RPP pemodelan, c) menyusun instrumen untuk observasi aktivitas siswa, d) menyusun instrumen untuk observasi pengelolaan pembelajaran BDR oleh guru, dan e) menyusun instrumen untuk observasi RPP guru.

Tabel 3: Rangkuman Analisi Hasil Observasi Siklus II

\begin{tabular}{|c|c|c|c|c|c|c|c|c|}
\hline \multirow[t]{2}{*}{ Item } & \multicolumn{5}{|c|}{ Nilai Observasi } & \multirow[t]{2}{*}{ Rerata } & \multirow{2}{*}{$\begin{array}{c}\text { Indikator } \\
\text { keberhasilan }\end{array}$} & \multirow[t]{2}{*}{ Keterangan } \\
\hline & Guru I & Guru II & Guru III & Guru IV & Guru V & & & \\
\hline $\begin{array}{l}\text { Kreatifitas dalam } \\
\text { Penyusunan RPP }\end{array}$ & $85 \%$ & $88 \%$ & $86 \%$ & $86 \%$ & $86 \%$ & $87 \%$ & $85 \%$ & Tuntas \\
\hline $\begin{array}{l}\text { Inisiatif Pengelolaan } \\
\text { Pembelajaran Daring }\end{array}$ & $87 \%$ & $90 \%$ & $90 \%$ & $87 \%$ & $85 \%$ & $88 \%$ & $85 \%$ & Tuntas \\
\hline Keaktifan Siswa & $87 \%$ & $90 \%$ & $85 \%$ & $97 \%$ & $85 \%$ & $88 \%$ & $85 \%$ & Tuntas \\
\hline Nilai Siswa & $79 \%$ & $82 \%$ & $78 \%$ & $80 \%$ & $81 \%$ & $80 \%$ & $75 \%$ & Tuntas \\
\hline
\end{tabular}

Hasil observasi RPP terhadap guru kelas 1, guru kelas 2, guru kelas 3, guru kelas 4, dan guru guru kelas 5 mendapat skor yaitu $87 \%$. Hasil observasi terhadap pengelolaan pembelajaran $\mathrm{BDR}$ melalui daring/online
Pelaksanaan Tindakan Siklus II peneliti melaksanakan pembinaan terhadap guru. Guru dikumpulkan secara berkelompok, dengan mematuhi protokol pemerintah yaitu pakai cuci tangan pakai air yang mengalir, atau hand sanitizer, masker, duduk dengan jarak 1 meter diberi pembinaan. Isi pembinaan berupa bagaimanakah membuat RPP yang lengkap, bagaimana mengelola pembelajaran BDR melalui daring yang baik, menarik, dan dapat mencapai tujuan, serta bagaimana dapat memusatkan perhatian siswa agar antusias dalam mengikuti pelajaran BDR melalui daring agar imun anak tetap terjaga dan juga dengan didampingi oleh orang tua masing-masing.

Observasi pembelajaran BDR melalui daring dilakukan oleh peneliti dan dibantu oleh kolaborator. Kolabulator mengobservasi peneliti dalam membuat RPP pembimbingan, saat peneliti melakukan pembimbingan, RPP KBM model, pengelolaan pembelajaran BDR melalui daring/online saat model mememberikan tugas tugas pembelajaran, dan keterlibatan siswa dalam mengikuti pembelajaran daring/online guru model. Peneliti melakukan observasi RPP guru, pengelolaan pembelajaran BDR saat guru memberikan tugas pembelajaran daring, dan keterlibatan siswa dalam mengikuti pembelajaran guru. Observasi dilakukan dengan tujuan untuk mengetahui tingkat partisipasi atau keaktifan siswa dalam proses pembelajaran daring/online. Hal ini juga sebagai bentuk evaluasi terhadap proses pembelajaran. Lembar observasi yang digunakan berupa lembar checklist. Indikator yang diamati adalah tingkat partisipasi siswa dalam proses pembelajaran BDR melalui daring/online. mendapat skor $88 \%$. Hasil observasi terhadap keaktifan siswa mendapat skor $88 \%$. Hasil observasi terhadap nilai yang diperoleh siswa mendapat skor $80 \%$. Indikator keberhasilan membuat RPP, Pengelolaan kelas, keterlibatan 
siswa ditetapkan $85 \%$, sedangan hasil belajar siswa ditetapkan $75 \%$. Perbandingan antara skor capaian dengan indikator keberhasilan menunjukkan adanya peningkatan antara siklus satu dan siklus dua. Bila dibandingkan dengan indikator keberhasilan sudah melampaui indikator keberhasilan atau tuntas.

Tabel 4: Progres Capaian Kompetensi Guru dari Siklus I ke Siklus II

\begin{tabular}{lcccl}
\hline \multicolumn{1}{c}{ Kompetensi } & Siklus I & Siklus II & Indikator Keberhasilan & \multicolumn{1}{c}{ Keterangan } \\
\hline $\begin{array}{l}\text { Kreatifitas dalam } \\
\text { Penyusunan RPP }\end{array}$ & $69 \%$ & $87 \%$ & $85 \%$ & $\begin{array}{l}\text { Dari siklus I ke siklus II } \\
\text { mengalami kenaikan 18 \% }\end{array}$ \\
\hline $\begin{array}{l}\text { Inisiatif Pengelolaan } \\
\text { Pembelajaran Daring }\end{array}$ & $76 \%$ & $88 \%$ & $85 \%$ & $\begin{array}{l}\text { Dari siklus I ke siklus II } \\
\text { mengalami kenaikan 12 } \%\end{array}$ \\
\hline Keterlibatan siswa & $71 \%$ & $88 \%$ & $85 \%$ & $\begin{array}{l}\text { Dari siklus I ke siklus II } \\
\text { mengalami kenaikan 17\% }\end{array}$ \\
\hline Hasil penilaian siswa & $70,4 \%$ & $80 \%$ & $75 \%$ & $\begin{array}{l}\text { Dari siklus I ke siklus II } \\
\text { mengalami kenaikan 9,6\% }\end{array}$ \\
\hline
\end{tabular}

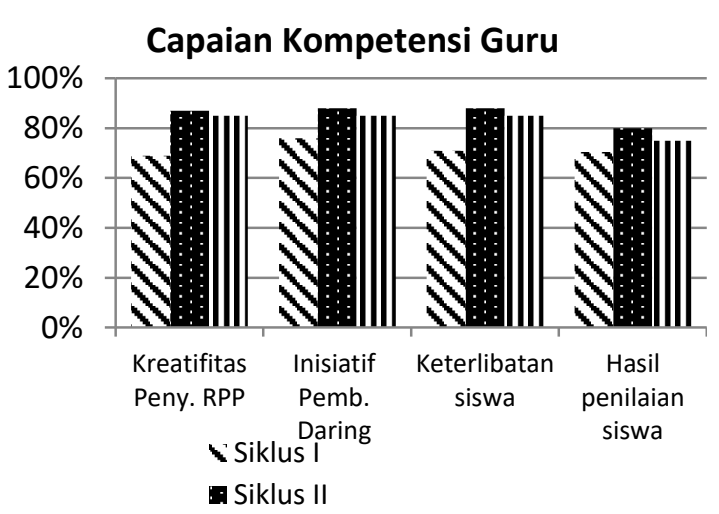

Gambar 2: Progres Capaian Kompetensi Guru dari Siklus I ke Siklus II

\section{SIMPULAN}

Berdasarkan uraian hasil penelitian yang dilakukan terhadap guru kelas 1, kelas 2, kelas 3 , kelas 4 dan guru klas 5 di SD Bungkus pada bulan Maret sampai dengan Mei 2020, maka dapat ditarik kesimpulan bahwa Model Pembelajaran daring dapat meningkatkan kreatifitas dan inisiatif guru di SD Bungkus, Kretek Bantul Pada masa pademi covid-19.

Saran yang perlu disampaikan, dalam Masa wabah pademi covid-19 diperlukan berbagai bentuk model pembelajaran agar guru, siswa bisa aktif dalam pembelajaran daring/online dengan menyenangkan, penuh tantangan, aktif dan kreatif didampingi oleh orang tua siswa tanpa mengurangi imun peserta didik, sehingga dalam teknik pemodelan adalah peneliti mengenal dengan siswa dalam pemberian tugas di rumah melalui daring/online di kelas yang akan menjadi objek pemodelan.

\section{DAFTAR PUSTAKA}

Depdiknas. 2003. UU RI No. 20 Tahun 2003 tentang Sistem Pendidikan Nasional. Jakarta: Depdiknas. 2004. Standar Kompetensi Guru Sekolah Dasar. Jakarta: Depdiknas.

Harususilo, Y.E. (2020). Belajar di Rumah. Diakses pada https://www.kompas.com/ edu/read/2020/04/06/195923371/belajardi-rumah-6-langkah-beri-siswa-tugasmembahagiakan?page $=$ all .

Permendiknas No 13 Tahun 2007 yaitu tentang standar kompetensi kepala sekolah madrasah. Jakarta: Depdiknas

PP No. 21 Tahun 2020 tentang Pembatasan Sosial Berskala Besar (PSBB).Jakarta

UU No. 6 Tahun 2018 tentang Kekarantinaan Kesehatan ; Dinkes Jakarta 